\title{
A Comparative Study on the Export Competitiveness of the Mineral Industries of the Mano River Union Countries in the US Market using the Shift Share Analysis
}

\author{
${ }^{1}$ Sheku Maddie Kamara, ${ }^{2}$ Sesay, Brima \\ ${ }^{1}$ School of Economics and Management, Nanjing University of Information Science and Technology, \\ Nanjing 210044, P. R. China. \\ ${ }^{2}$ School of Economics, Wuhan University of Technology, Wuhan 430070, P.R. China
}

\begin{abstract}
The mineral sectors of the Mano River Union countries are important contributors to their economic growth. More than half of the export revenues of these countries are derived from the extraction and exportation of minerals. This study was conducted in order to assess the competitiveness of the mineral industries of the Mano River Union countries vis-à-vis Sierra Leone, Guinea, and Liberia. The shift share analysis was applied in order to identify the industries that have comparative advantages in the mineral sectors of the sample countries. The United States market was selected as the base of the research upon which the results were analyzed. The total minerals exports of the three countries were classified into five (5) groups based on the Standard International Trade Classification (SITC2-3). The relevant categories were as follows: (1) Iron and Ferro-Alloy Metals (Fe), (2) Non-ferrous Metals (NFM), (3) Industrial Minerals (IM), (4) Precious Metals (PM), and (5) Mineral Fuel (MF). For the purpose of shift share analysis, the study period were divided into two separate terminal periods of 2005-2009, and 2010-2014, taking into consideration the export data runs for ten (10) years. Precisely for Sierra Leone, the NFM, PM and IM industries all show positive correlation values, whilst the Fe industry on the other hand shows a negative correlation value. The result further confirms that the NFM industry was the most competitive industry, whilst the Fe industry was the least competitive. In the case of Guinea, the NFM, IM and MF industries all show positive correlation values, whilst the PM industry shows negative correlation value. The NFM industry was the highest performer, and therefore the most competitive industry. For Liberia, the Fe industry shows positive net shift, whilst the IM industry shows a negative net shift. Overall, the most competitive in the US market was Guinea, followed by Sierra Leone and Liberia respectively.
\end{abstract}

Key words: competitiveness, shift-share, net shift, export growth, Mano River Union,

\section{Introduction}

The Mano River Union (MRU) is a regional integration that is made up of the governments of Liberia, Sierra Leone, Guinea, and Ivory Coast. The Mano River Union came into existence in 1973 when the government of Sierra Leone and Liberia saw the need for establishing a sub-regional cooperation, with the aim of fostering and coordinating economic development between the then two member states (Sierra Leone and Liberia). It was later on joined by Guinea and Ivory Coast in 1980 and 2008 respectively. Today, the Mano River Union is directed not only towards economic developments of the member countries, but also in the areas of governance, agriculture, industrializations, peace and security, mineral resources management, amongst many others, all gearing towards poverty alleviations within the respective countries, as well as improving the living standards of their citizens.

However, it could be recalled that prior to the outbreak of the Ebola epidemic within the sub-region in early 2014, the Mano River Union countries continue to register strong economic performance. Economic activities in the subregion continue to increase impressively. Before the Ebola outbreak, Sierra Leone, Liberia, and Guinea have all 
recorded 11.3\%, 5.9\%, and 4.5\% growth rates of Gross Domestic Products (GDP) respectively (MRU, 2015). The per capita incomes of these countries have increased, and large numbers of multinational companies continue to flock into the mineral sectors of these countries. Based on the figures from the World Bank statistics in 2013, the GDP of Guinea was estimated at 6.1 billion dollars with a per capita income of 460 dollars. Sierra Leone on the other hand was 4 billion dollars with a gross per capita income of 660 dollars, whilst Liberia was 1.95 billion dollars with a per capita income of 410 dollars. This growing trend in the economic performance of these countries is mainly attributed to the boom in the mineral sectors of these countries. The sub-region continues to experience overwhelming influx of mining companies from global powers such as China, the United States, India, Australia, and the European Union (EU), which has resulted to increase explorations and mining activities in the sub-region.

This study compares the export competitiveness of the mineral industries of the Mano River Union countries- Sierra Leone, Liberia, and Guinea. The mineral industries of these countries constitute significant parts of their economies, and thus an important sector for economic growth. As they engaged in the mining and exportations of similar mineral commodities such as gold, iron ore, diamonds, copper, bauxites, and many other mineral resources, there is the tendency of export competition or export rivalry among them. This study therefore seeks to provide a comparative study on the export competitiveness of the mineral industries of these countries using the shift share methodology. According to the world competitiveness yearbook, Competitiveness is when a country is able to create and maintain an environment or a platform capable of sustaining additional value creation for its enterprises, as well as creating prosperity for the citizens of that country. Competitiveness is the ability of a region or a country to export more in value added terms than its imports (Atkinson, 2013). Competitiveness is about productivity, which encompasses both tangible and intangible (image of the country/company, brand equity) factors (Verma, 2002). Export competitiveness therefore is when a country is able to produce and sell goods and services beyond its borders at the right time, at the right place, at the right price, and at the right quality that enhances its long-term competitiveness and thus economic prosperity for its peoples.

Following the introductory section, that is section one, the rest of the paper is structured as follows: Section two provides a brief review of the theoretical and empirical literatures that focus on competitiveness using shift share analysis, while section three presents the data and methodology of the study and examines its statistical properties, including parameter constancy. Section four provides analysis of empirical results and discussion and section five offers conclusion and policy recommendation.

\section{Literature Review}

Voon (1998) examined the export competitiveness of China and ASEAN in the US market from 1980-1994. The study classified the total exports of China and ASEAN 4; Malaysia, Thailand, Indonesia, and Singapore into four product categories, namely; agricultural, primary, more labor intensive, and less labor intensive manufactures. From the study, China outperformed the other ASEAN economies as exporters to the U.S market. Singapore on the contrary was less competitive than the other countries.

Chern et al. (2002) examined Singapore's export competitiveness in the U.S, and EU export markets as exporters of electronics and chemicals from 1988-2001. By using the dynamic shift share analysis to carry out their assessment, they observed that the electronic exports of Singapore in overall performed well over the period of 1988-1995. This was based on the positive net shift relative to Taiwan, Malaysia, Korea, China, and Hongkong chosen on the basis that they are the closest competitors to Singapore in terms of export to the U.S and EU markets. Singapore performed relatively well as a result of the robust foreign direct investments in the electronic sector.

Wilson et al. (2005) assessed the export competitiveness of China to the newly industrialized East Asian countries as exporters of electronics in the U.S, EU, and Japanese markets over the period of 1988 to 2001. This study revealed that China is a strong but not a dominant competitor as exporter of electronic products in the U.S, EU, and Japanese market. China comes up as the biggest or dominant player in telecommunication and consumer electronics products.

Herath et al. (2011) applied the dynamic shift share analysis to examine the economic growth of West Virginia in terms of employment and its policy implications. The research was conducted using employment data from the period of 1970-2007. They divided the employment sector of West Virginia into three main sectors - mining, 
manufacturing, and agriculture. Based on the research, they found that there was a decrease in employment of West Virginia from the period of 1970 to 2007, thus the manufacturing, mining, and that of the agricultural sector are no longer the main cornerstones of the economy as they used to be.

Al-Mamun et al. (2015) applied the shift share analysis in order to assess the export growth of Malaysia's electrical and electronic products. The assessment was carried out by selecting fifteen (15) countries as the reference economies from 2006-2008 and 2009-2011. Through the application of the shift share technique, and the constant market share simultaneously, the study revealed that the general export market has increased based on the computational value, with the exception of the US, Japan, and Thailand. Singapore and Cambodia emerged with the highest and lowest growth rate respectively.

Muhammad and Yaacob (2008) in another study researched on the export competitiveness of Malaysian electrical and electronic product comparatively to its closest competitors, namely; China, Indonesia, and Thailand. They used the revealed comparative advantage index, and the constant market share model to assess the competitiveness of Malaysia, and the other selected economies from the period of 1990-2004, divided into three distinct periods of period 1, 2 and 3. Based on the calculated value using the constant market share, the study revealed that there was increased competitiveness of Malaysia's electrical and electronic products in period 1, and therefore increased in export value. In period 2, there was increased export value, but was however not because of its competitiveness but due to the upsurge in the need for electrical and electronic equipments globally. In period 3 however, there was still an increase in the value of export as a result of the combined effect of both structural and competitive residual. Moreover, using the revealed comparative advantage index, the study shows that Malaysia outperformed the other reference economies in the U.S market, while Indonesia and China dominate the markets of Singapore and Hong Kong respectively.

In another review, Sheikh (2015) examined the competitiveness of cotton export of India using the shift share analysis and the constant market share analysis for a period of 18 years (1993/4-2011/12). This study found that export of cottons remained stable throughout the period of assessment. There was a positive trend in the actual change in export only after 2002, and growth was said to be negative only for 8 years out of a total of 18 years. The increase competitiveness of the cotton export of India was however ascribed to the market share effect.

\section{Data and Methodology}

The data from the US Census Bureau Foreign Trade Statistics for each of the three countries are used to examine the export competitiveness of the mineral industries of the three Mano River Union countries- Sierra Leone, Guinea, and Liberia. The data from the US Census Bureau Foreign Trade Statistics used in this research for each of the three countries are chosen based on the authenticity, clarity, and continuity of their records. The data used in the study covers the period from 2005-2014. The method used to carry out the analysis was by applying the Shift Share Methodology. The shift-share analysis estimate how competitive was each of the three Mano River Union countries in the United States markets as the largest single market over the period of 2005-2014.

However, it will be time consuming and daunting in looking at each of the minerals exported by each of the three Mano River Union countries individually or exclusively. The total exports of these counties were therefore classified into five (5) categories based on the Standard International Trade Classification (SITC 2-3) groupings. The various categories are as follows: (1) Iron and Ferro-Alloy Metals ( $\mathrm{Fe}$ ) comprising; nickel, iron, steel making materials, (2) Non-ferrous Metals (NFM) including aluminum, bauxite, copper, sulfur, (3) Industrial Minerals (IM) including diamonds, (4) Precious Metals (PM) including gold, platinum, silver and (5) Mineral Fuels (MF) including crude oil, crude petroleum, uranium, and natural gas. Also, for the purpose of shift share analysis, the study period were divided into two separate terminal periods of 2005-2009, and 2010-2014, taking into consideration the export data runs for ten (10) years.

Moreover, in order to arrive at the conclusion on which country was competitive, and in which industry category was the said country competitive relative to the other countries, several shift share calculations were made based on the ten-year data for which our study covers. The relevant data evaluation procedures and analysis are as follows: 


\subsection{Growth Rate}

The growth rates, otherwise known as the rates of growth for all the industries in each of the three countries were calculated by dividing the total of the exports of the terminal period by the total of the initial period. From the calculation, the different mineral industries for the three countries- Sierra Leone, Guinea, and Liberia all showed positive growth rates in their over the period of ten years for which our data covers.

$$
K=\frac{\sum_{j=1}^{m} V_{j, t}}{\sum_{j=1}^{m} V_{j, t-1}}
$$

\subsection{Actual Change}

For all the three countries- Sierra Leone, Guinea, and Liberia, in order to determine the absolute growth value for each mineral category, the actual change for each mineral industry were calculated. The actual change basically here refers to the differences in values from the initial period to the terminal period. Let say for example $V_{j, t}$ represents the export values for industry $\mathrm{j}$ during the end of the terminal period $\mathrm{t}$, and at the same time $\Delta V_{j}$ represents the actual change that occurs in industry $\mathrm{j}$ over the period for which the data covers. The actual change will therefore be represented as follows:

$$
\Delta V_{j}=V_{j, t}-V_{j, t-1}
$$

By the application of these formula, if;

$\Delta V_{j}>0$ It means there was an increase in the export of minerals in industry $\mathrm{j}$

$\Delta V_{j}=0$ It means there was neither an increase nor a decrease in export of industry $\mathrm{j}$, rather it remain unchanged

$\Delta V_{j}<0$ then there was a decline in the export of industry $\mathrm{j}$

\subsection{Expected Value}

The expected value of our growth values were also calculated for all the mineral classifications for all the three countries at the end of the terminal period. The expected value is thus calculated as;

$$
E\left(V_{j, t}\right)=K\left(V_{j, t-1}\right)
$$

Where $E\left(V_{j, t}\right)$ is the expected value and $K$ is the growth value

\subsection{Expected Change}

The difference between the expected value and that of the actual value known as the expected change for all industrial categories in each of the three countries were also ascertained. The expected change is expressed as;

\subsection{Net Shift}

$$
E\left(\Delta V_{j}\right)=E\left(\Delta V_{j, t}\right)-V_{j, t-1}=V_{j, t-1}(K-1)
$$

The difference between the actual change and the expected change for each of the five industrial categories in each of the three countries is known as the net shift. If the difference is positive for any industry, then there was a positive 
shift in the exports of minerals in that industry. In a case where the difference is negative, it means there was a negative shift in the export of minerals for that industry over the period of 2005-2014 for which the data covers. The net shift in this case is represented as;

$$
N_{j}=\Delta V_{j}-E\left(\Delta V_{j}\right)
$$

\subsection{Total Absolute Net Shift}

The total of the entire positive net shift and the total of the entire negative net shift give the total absolute net shift. The total absolute net shift is thus express as;

$$
S=\frac{\sum_{j=1}^{m}\left[\Delta V_{j}-E\left(\Delta V_{j}\right)\right]}{2}=\sum_{j=1}^{p} N_{j}^{t}
$$

\section{Empirical Results Discussions}

In analyzing the results of the shift share computations, it is important to note that, the minerals with the highest Actual Change (AC) for each of the three Mano River Union Countries- Sierra Leone, Guinea, and Liberia, are the minerals in which the respective countries have competitive edge relative to the other categories. A positive net shift for any category (SITC 2-3) indicates or shows that there was a positive shift in the market for that mineral, whilst a negative shift shows or tells that there was a negative shift in the market of that mineral.

Based on the calculated net shift and net shift percentage figures (Table 1) for Sierra Leone regarding the exports of Iron and Ferro-Alloy metals (Fe), Non-Ferrous Metals (NFM), Precious Metals (PM), Industrial Minerals (IM), and Mineral Fuels (MF), the Non-Ferrous Metals (NFM) industry, the Precious Metals industry (PM), and the Industrial Minerals (IM) industries all shows a positive correlation values of $154.29 \%, 11.43 \%$, and $57.14 \%$ respectively. Iron and Ferro-alloy industry on the other hand shows or revealed a negative correlation value of $(-22.86 \%)$. The NonFerrous Metals (NFM) industry shows or registered the highest percentage of net shift, followed by the Industrial Minerals (IM) industry. This highest net shift for the Non-Ferrous Metals (NFM) industry indicates that the NonFerrous Metals (NFM) is outperforming the other industries in terms of exports of minerals by the various industries to the United States (US) market. The Non-Ferrous Metals (NFM) industry among all the four mineral export industries of Sierra Leone is therefore the most competitive industry in the United States market.

The shift share computational results however did not tell us or show us why the Non-Ferrous metals (NFM) industry is the most competitive, but only shows or reveals the competitiveness of the industry, as compared to the Iron and Ferro-alloy Metals (Fe), the Industrial Minerals (IM), and Precious Metals (PM) industries. The shift share technique does not tell us what made the industry (non-ferrous metals) the most competitive.

The shift share technique is therefore helpful in identifying investment areas within an industry, or in the midst of industries so that those charges with the responsibility of governance or those responsible for managing the affairs of such industry can help the industry continues to perform excellently well, or match up with other high performing industries. However, coming next to the Non-Ferrous Metals (NFM) industry as the highest performer in terms of the net shift figure calculated from (Table 1) is the Industrial Minerals (IM) industry. 
Table 1: Correlation table for Iron and Ferro-Alloy, Non-Ferrous Metals, Precious Metals, Industrial Minerals, and Mineral Fuels for Sierra Leone in the US market (in M\$US)

\begin{tabular}{|l|l|l|l|l|l|l|l|}
\hline $\begin{array}{l}\text { Minerals } \\
\text { (SITC 2-3) }\end{array}$ & $\begin{array}{l}\text { Initial } \\
\text { period }\end{array}$ & $\begin{array}{l}\text { Terminal } \\
\text { period }\end{array}$ & $\begin{array}{l}\text { Actual } \\
\text { change }\end{array}$ & $\begin{array}{l}\text { Expected } \\
\text { value }\end{array}$ & $\begin{array}{l}\text { Expected } \\
\text { change }\end{array}$ & Net shift & $\begin{array}{l}\% \text { of net } \\
\text { shift }\end{array}$ \\
\hline $\begin{array}{l}\text { Iron and Ferro- } \\
\text { Alloy }\end{array}$ & 32 & 79 & 47 & 79.04 & 47.04 & -0.04 & $-22.86 \%$ \\
\hline $\begin{array}{l}\text { Non-Ferrous } \\
\text { Metals }\end{array}$ & 92 & 1.19 & -90.81 & 0.92 & -91.08 & 0.27 & $154.29 \%$ \\
\hline Precious Metals & 5.04 & 4.40 & -0.64 & 4.38 & -0.66 & 0.02 & $11.43 \%$ \\
\hline $\begin{array}{l}\text { Industrial } \\
\text { Minerals }\end{array}$ & 22 & 32 & 10 & 31.90 & 9.90 & 0.1 & $57.14 \%$ \\
\hline Mineral Fuels & - & - & - & - & - & - & - \\
\hline
\end{tabular}

The Industrial Mineral (IM) industry was the second big performer, in order words, the second most competitive industry amongst the four mineral export industry categories, though far from matching up with the Non-Ferrous Metals industry (NFM) based on the calculated net shift. Moreover, the negative correlation value for the Iron and Ferro-alloy Metals (Fe) indicates or shows that there is a negative shift in the market for Iron and Ferro-Alloy Metals $(\mathrm{Fe})$ in the United States market. The Iron and Ferro-Alloy Metals ( $\mathrm{Fe})$ industry in this case is not performing well or less competitive as compare to the Non-Ferrous Metals (NFM), Precious Metals (PM), and the Industrial Minerals (IM) industries in the United States market all of which shows positive correlations, and hence positive shifts in their respective mineral industries exports to the united States market. Looking at the correlation table, the Iron and Ferro-alloy industry of the country was booming in terms of the actual change values ascertained, but the shift share results for this industry revealed or showed a negative net shift. A particular industry, or a set of industries may be booming, but the shift share results ended up showing a negative net shift for that industry. This is as a result of the fact that, let say a certain country may be undergoing a decline at the national level, but the shift share result on the other hand shows or comes up with a positive values. This however shows that the factors responsible for the decline in national growth have little or no connection, in order words any influence on such boom. Also, an industry may be declining but the results of the share effect shows a positive net shift for that industry. In such a case, there is a hidden prospect in that industry that requires a thorough and a careful investigation in a bid to identify and salvage such problems.

Overall, the Non-Ferrous Metals (NFM) industry was the highest performer among all the four industrial categoriesIron and Ferro-Alloy Metals (Fe), Non-Ferrous Metals (NFM), Precious Metals (PM), and the Industrial Minerals (IM) industries. In other words, the Non-Ferrous Metals (NFM) industry is the industry that registered the highest net shift value over the ten (10) years period of 2005-2014 under review. Followed by the Non-Ferrous Metals (NFM) industry in terms of registering the highest net shift value was the Industrial Minerals (IM) industry registering the second highest net shift value after the Non-Ferrous Metals (NFM) industry. Followed by the industrial minerals (IM) industry is the Precious Metals (PM) industry. All these three industries- the Non-Ferrous Metals (NFM) industry, Industrial Minerals (IM) industry, and the Precious Metals (PM) industry registered positive net shifts values, and therefore favorable growth or boom in their respective industry, though the Precious Metals (PM) industry was not that extremely booming. The worst performer, in other words the industry that performs poorly in the United States market in terms of the net shift value was the Iron and Ferro-Alloy Metals (Fe) industry. The Iron and Ferro-alloy industry is the only industry among the five minerals classifications industry that showed a negative net shift value. The reason for this poor performance was however not reveals based on the limitations of the shift share technique, as the shift share computational results however did not tell us or show us why the Iron and Ferro-Alloy Metals (Fe) industry was not competitive, rather the shift share analysis reveals only 
the competitiveness of the industry as compared to the other industries- Non-Ferrous Metals (NFM) industry, Industrial Minerals (IM) industry, and the Precious Metals (PM) industry respectively. Advancing the reason or reasons as to why this industry was the least competitive or the worst performer among the other export minerals industries in the United States market is the work of industrial analysts, as they are the ones that read the trends of local industries and bring out the factors that swift or impede the performance of industries in a given country, or within a region as a whole.

However, in the case of Guinea (Table 2), the Non-Ferrous Metals (NFM) industry, the Industrial Minerals (IM) industry, and the Mineral Fuels (MF) industry show positive correlation values of $69.57 \%$, 30.43\%, and $1.45 \%$ respectively, whilst the Precious Metals (PM) industry on the other hand showed or revealed a negative correlation value of $(-2.90 \%)$. The Iron and Ferro-Alloy Metals $(\mathrm{Fe})$ industry however remained almost unchanged, and therefore no shift within the ten year period of 2005-2014 as the study framework for which the data runs. The Non Ferrous metals (NFM) industry registered the highest percentage of net shift, with a net shift percentage of $69.57 \%$. Followed by the Non-Ferrous Metals (NFM) industry is the Industrial Minerals (IM) industry with a net shift percentage of $30.43 \%$. This highest net shift percentage for the Non-Ferrous Metals (NFM) industry of Guinea shows that the Non-Ferrous Metals (NFM) industry of the mineral sector of Guinea performed better than the other industries in terms of exports of minerals in the United States (US) market. The Non-Ferrous Metals (NFM) industry among all the five mineral exporting industries is therefore the most competitive industry in the mineral sector of the country. The shift share computational results however did not tell us or show us why the Non-Ferrous Metals (NFM) industry in this case is the most competitive industry; rather its only showed or revealed the competitiveness of the industry (the Non-Ferrous Metals), as compared to the Iron and Ferro-alloy Metals (Fe) industry, Precious Metals (PM) industry, Industrial Minerals (IM) industry and the Mineral Fuel (MF) industry.

This however can be attributed to several factors, some of which may likely be as a result of increase production of non- ferrous metals by the country, or possibly lower export duties in the Non-Ferrous Metals (NFM) industry of the United States market. For instance in 2010, the productions of alumina in the country increased significantly by $13 \%$ as compared to the growth percentage of the country in 2009 , which was by $12 \%$. There was a production of about 597,000 metric tons of alumina in the country in 2010, compared to that of 530,000 metric tons increase in 2009. Also, a number of significant changes took place in the mineral sector of the country in that year, with the Anglo Aluminum Corp., a Canadian multinational corporation securing bauxite production and exploration license in the year for the exploration of 406 square-kilometer, and 130 square-kilometer projects for two major bauxite producing region in the country. This increase production, coupled with other favorable conditions may likely be one of the reasons for the highest net shift percentage of the non-ferrous metals exports to the United States by Guinea.

However, coming next to the Non-Ferrous Metals (NFM) industry as the highest performer in terms of the net shift figure calculated from (Table 2) is the Industrial Minerals (IM) industry. The Industrial Minerals (IM) industry of the mineral sector of Guinea was the second big performer, in order words, the second most competitive industry amongst the five mineral export industries in the country. According to the Kimberley Process Rough Diamond Statistics on Guinea in 2008, the production of diamonds increased from 474,000 carats of diamonds in 2006 to 1,019 thousands carats in 2007. Sometimes in November in the same year of 2007, the West African Diamonds Plc, previously known as the African Diamonds before the change of the name, promulgated the recovery of four (4) big diamonds all from 3.8 to 9.2 carats based on property all as a result of the sampling. All these and other factors may be the reason for the positive shift in the market of the Industrial Minerals (IM) industry.

Moreover, the Precious Metals (PM) industry on the other hand registered a negative net shift value. Only the Precious Metals (PM) industry recorded a negative net shift value amongst the various mineral industries of Guinea. The negative correlation value for the Precious Metals (PM) industry indicates that there was a negative shift in the markets for precious metals in the United States market. The Precious Metals (PM) industry in this case was less competitive in terms of export to the United States market as compared to the other industries. This however can be attributed to several reasons. Gold production in the country decreased for most of the years in which the study data covers. Production of gold in 2010 decreased by $16 \%$, seeing all production of gold excluding those from artisanal level decreased from that of $18,091 \mathrm{~kg}$ in 2009 , to that of $15,217 \mathrm{~kg}$. Also in 2012, as a result of low processing volumes of gold, suspension in some of the mines due to riots in the country amongst others saw all the three major 
active gold mine- Lefa, Kiniero, and Siguiri in the country experienced a dropped in the volume of gold produced in the country. The production of gold decreased by $12.3 \%$ and $12.8 \%$ in the Lefa, and Kiniero mines respectively. Whilst for the Siguiri mine, there was a little dropped in the quantity of gold produced, seeing it moving from 9113 $\mathrm{kg}$ to $9020 \mathrm{~kg}$.

In the case of the Mineral Fuels (MF) industry, there was a positive shift in the market though the shift was not that high as compared to that of the non-ferrous metals industry and the industrial minerals industry. The country however does not produce petroleum fuels neither crude oil, or gas in the early years of our study duration, or the period for which the data covered. Guinea however relies on import for petroleum fuels and other natural gases. The only mineral fuels commodity produced by the country is uranium. Production of uranium is very recent, and the volume produce in the country is not substantial for competitive exports. The Mineral Fuels (MF) industry in this case was less competitive as compare to the Non-Ferrous Metals (NFM) industry, and the Industrial Minerals (IM) industry all of which shows positive correlations values, and hence positive shifts in their respective mineral industries with regards to exports of minerals to the United States market.

Table 2: Correlation table for Iron and Ferro-Alloy, non-ferrous metals, precious metals, industrial minerals, and Mineral fuels for Guinea in the US market (in M\$US)

\begin{tabular}{|l|l|l|l|l|l|l|l|}
\hline Minerals(SITC) & $\begin{array}{l}\text { Initial } \\
\text { period }\end{array}$ & $\begin{array}{l}\text { Terminal } \\
\text { period }\end{array}$ & $\begin{array}{l}\text { Actual } \\
\text { change }\end{array}$ & $\begin{array}{l}\text { Expected } \\
\text { value }\end{array}$ & $\begin{array}{l}\text { Expected } \\
\text { change }\end{array}$ & Net shift & $\begin{array}{l}\% \text { of net } \\
\text { shift }\end{array}$ \\
\hline $\begin{array}{l}\text { Iron and Ferro- } \\
\text { Alloy }\end{array}$ & 0.0245 & 0.0245 & - & 0.0245 & - & - & - \\
\hline $\begin{array}{l}\text { Non ferrous } \\
\text { metals }\end{array}$ & 346 & 388 & 42 & 387.52 & 41.52 & 0.48 & $69.57 \%$ \\
\hline Precious metals & 7.01 & 7.76 & 0.75 & 7.78 & 0.77 & -0.02 & $-2.90 \%$ \\
\hline Industrial minerals & 42.77 & 7.05 & -35.72 & 6.84 & -35.93 & 0.21 & $30.43 \%$ \\
\hline & & & & & & & \\
\hline
\end{tabular}

Overall, among all the five mineral industries- Iron and Ferro-Alloy metal (Fe), Non-Ferrous Metals (NFM), Precious Metals (PM), Industrial Minerals (IM), and Mineral Fuels (MF), the Non-Ferrous Metals industry was the highest performer; in other words, the Non-Ferrous Metals (NFM) industry registered the highest net shift value over the ten (10) years period of 2005-2014 under review. Followed by the Non-Ferrous Metals (NFM) industry in terms of registering the highest net shift value was the Industrial Minerals (IM) industry registering the second highest net shift value after the Non-Ferrous Metals (NFM) industry. Followed by the Industrial Minerals (IM) industry in terms of competitiveness is the Mineral Fuels (MF) industry. Only the Precious Metals (PM) industry registered negatives net shift value. The negative net shift value for the Precious Metals (PM) industry shows that the Precious Metals (PM) industry performed poorly as compared to the other industries- the Non-Ferrous Metals (NFM), the Industrial Minerals (IM), and the Mineral Fuels (MF) industries. The reason or reasons for the abysmal performance was however not revealed based on the limitations of the shift share technique. The shift share results however did not tell us or show us why this industry was less efficient as compared to the other industries.

In the case of the export competitiveness of the various mineral industries of Liberia's mineral sector (Table 3) in the United States market, the Iron and Ferro-Alloy Metals (Fe) industry shows a positive net shift percentage of $100 \%$, with a net shift value of 0.01 , whilst the Industrial Minerals (IM) industry shows a negative net shift 
percentage of $-100 \%$. However, the other industries- Non-Ferrous Metals (NFM), Precious Metals (PM), and the Mineral Fuels (MF) resulted to zero (O) net shifts. There was no export value recorded by the country for precious metals throughout the ten year period of 2005-2014 for which the data covers. The shift share technique basically cannot tell us what was responsible for this. Several factors however may be the reasons as to why there was no record made for precious metals throughout the period for which the export data covers. One reason for this could be, there were no major productions of precious metals in the country throughout our export data period. Productions of precious metals might have been purely at artisanal level, and as such no exports of precious metals by the government.

Also, another reason that can be attributed to this is that, there was a better market(s) for the country's precious metals other than the United States market. Other rival markets other than the United States market might have dominated the country's precious metals industry, and as such all exports were directed to those countries. For instance, the production of rough diamonds decreased by $18 \%$ to 34,271 carats in 2012 as compared to the 41,932 carats produced in the country in 2011. The government attributed this declined in production of diamonds to increase in labour inputs for gold production in the precious metals industry. Gold production in the country increased by $43 \%$ in 2012 to $641 \mathrm{~kg}$ compared to that of $448 \mathrm{~kg}$ produced in the country in 2011 (Central Bank of Liberia, 2012). Based on this export data, it is prudent enough to conclude that there were better markets for the country's precious metals industry other than the United States market. For the Industrial Minerals (IM) industry, diamond production decline in the country in most of the years for which our export data runs.

Table 3: Correlation table for Iron and Ferro-alloy, non-ferrous metals, precious metals, industrial minerals, and Mineral fuels for Liberia in the US market (in M\$US)

\begin{tabular}{|l|l|l|l|l|l|l|l|}
\hline $\begin{array}{l}\text { Minerals(SIT } \\
\mathrm{C})\end{array}$ & $\begin{array}{l}\text { Initial } \\
\text { period }\end{array}$ & $\begin{array}{l}\text { Terminal } \\
\text { period }\end{array}$ & $\begin{array}{l}\text { Actual } \\
\text { change }\end{array}$ & $\begin{array}{l}\text { Expected } \\
\text { value }\end{array}$ & $\begin{array}{l}\text { Expected } \\
\text { change }\end{array}$ & Net shift & $\begin{array}{l}\% \text { of net } \\
\text { shift }\end{array}$ \\
\hline $\begin{array}{l}\text { Iron and } \\
\text { Ferro-alloy }\end{array}$ & 0.046 & 0.022 & -0.02 & 0.02 & -0.03 & 0.01 & $100 \%$ \\
\hline $\begin{array}{l}\text { Non ferrous } \\
\text { metals }\end{array}$ & - & - & - & - & - & - & - \\
\hline $\begin{array}{l}\text { Precious } \\
\text { metals }\end{array}$ & 0.17 & 0.18 & 0.01 & 0.18 & 0.01 & - & - \\
\hline $\begin{array}{l}\text { Industrial } \\
\text { minerals }\end{array}$ & 3.00 & 1.91 & -1.09 & 1.92 & -1.08 & -0.01 & $-100 \%$ \\
\hline Mineral fuels & 11.02 & 25.13 & 14.11 & 25.13 & 14.11 & - & - \\
\hline
\end{tabular}

The productions of minerals were however centered on the precious metals industry in the early years of the study period, and have been later on centered on the Iron and Ferro-Alloy Metals $(\mathrm{Fe})$ industry. There was no export value of industrial minerals by Liberia to the United States in the early years of 2005, 2006, and 2007. This shows that Liberia did no trade of industrial minerals with the United States for these years. The country recently starts trading industrial minerals with the United States market, starting from 2008 on to the end of the years under study though not at substantial amount. These were the only years for which export data for industrial minerals was available. Since then, the Industrial Minerals (IM) industry continues to experience decline in production. Productions were little higher in the early years of trading, but have been experiencing decline. 


\section{Conclusion and Recommendations}

This research was conducted in order to provide a comparative study on the export competitiveness of the mineral industries of the Mano River Union countries- Sierra Leone, Guinea, and Liberia. The method used to carry out the assessment was the shift share analysis in order to identify industries that are seen to have comparative advantages in the mineral sectors of all the three Mano River Union countries. For the purpose of shift share analysis, the study period were divided into two separate terminal periods of 2005-2009, and 2010-2014, taking into consideration the export data runs for ten $(10)$ years.

Based on the findings, the most competitive industry for Sierra Leone's mineral sector was the Non-Ferrous Metals (NFM) industry. Followed by this industry is the Industrial Minerals (IM) industry, which is the second most competitive mineral industry of the country. The worst performer in terms of competitiveness in the US market was the Iron and Ferro-Alloy (Fe) industry. These industries (Non-Ferrous Metals and the Industrial Mineral) have high export potentials for the country. Therefore, by focusing on these industries, the country would be able to effectively and efficiently produce these minerals in large quantities for exports to the US markets as well other markets other than the US market at a competitive amount. Also, the first step to benefitting from mineral resources is mineral explorations. Through mineral explorations, the concentrations of minerals for mining purposes are identified. It is therefore much more prudent to embark on increase mineral explorations as it will resulted to a worthy investment should the mineral concentrations are actually discovered.

With regards to the Iron and Ferro-Alloy (Fe) industry, which is the only industry that registered a negative net shift value, it is possible that this industry has some hidden unique factors that when probe well and come up with a conclusion as to what is responsible for not being competitive may translate to increase productivity in this industry as well as enhances its export competitiveness.

In the case of Guinea, the Non-Ferrous Metals (NFM) industry was the highest performer. Both the Industrial Mineral Industry and the Mineral Fuels industry also performed relatively well. The Precious Metals industry was the only industry that was not competitive comparatively to the others. The reason(s) for the poor performance of this industry relative to the other industries was however not revealed based on the limitations of the shift share technique. Therefore, it is advisable that the Precious Metals (PM) industry is probe well and come up with a conclusion as to why this industry is inefficient as compared to the others. It is possible that this industry has some hidden unique factors that when probe well and come up with a conclusion as to what is responsible may translate to increase productivity in this industry and hence stimulates its competitiveness.

However, as the country is virtually the most competitive country of the three Mano River Union (MRU) countries in the US market, increase labour productivity such as government investment in physical capital, human capital, and new technology will continue to increase the competitiveness of the country's various mineral industries relative to Sierra Leone and Liberia.

In the case of Liberia, there were no productions neither exports of non-ferrous metals throughout the period for which our data covered. There was no change in the export of precious metals throughout the ten years period of 2005-2014 for which our data covered. Based on the calculations, the actual change was exactly the same as the expected change. In this case the Precious Metals (PM) industry remains static throughout the period. For the Iron and Ferro-Alloy Metals (Fe), there was a positive 100\% shift in the industry, whilst for the Industrial Minerals (IM) industry there was a negative shift of $-100 \%$. Overall for all the three countries, Liberia was the least competitive in terms of mineral exports to the United States.

It is recommended that the country embark on surveys of skills need benchmarked against the other two competitor countries (Sierra Leone and Guinea) in order to outcompete or match up with them. Through this, skills gaps in potential areas of comparative advantage of these countries are identified.

Increase labour productivity in the various mineral industries will increase the country's export of minerals. Through government initiative of investing in physical capital, human capital, and new technology, it is obvious that the mineral sectors of the country will become competitive as well. The introduction of new technology coupled with 
the skills needed to operate the facilities will increase the productivity of the various mineral industries of the country. For example, the introduction of a new diamond treatment plant of about $180 \mathrm{t} / \mathrm{h}$ by OCTEA in the industrial mineral industry of Sierra Leone in 2012 brought about increase productivity in the industrial mineral industry of the country, and hence increases the export of diamonds by the country.

Finally, the decade rebel incursion in the country destroyed the most needed infrastructure of the country, as well halting all major mining activities in the country. These inadequate infrastructural facilities impeded the export competitiveness of the country to a larger extent. Though the country's mining industry have experienced significant revival in the past few years, there is still much more to do. As the export competitiveness of a country is significantly compromised due to poor infrastructural facilities, government expenditure on the infrastructure of the county will be critical to the export success of the country to a larger extent.

Moreover, Asian countries especially China and India have become major players in the continent's mineral sectors in recent years. For instance, in 2012, China alone accounted for about $17 \%$ of the world's minerals imported by value. About US $\$ 100$ billion worth of minerals were purchased by China in 2012 from a total of 100 countries according to KPMG-Mining in Africa towards 2020. Out of a total of the 100 countries from which these purchases were made, 23 of them were from Africa. It would therefore certainly be an insightful research to carry out a similar research on the export competitiveness of these countries (MRU countries) in the Asian markets

\section{References}

[1] Al-Mamun, A., Rahman, M.K., Taufiq, M., and Muzzammir, 2015. A Shift Share Analysis of Electrical and Electronic Products: An Overview and Assessment of Export Growth of Malaysia. Journal of Asian Social Science Vol.11 (10), $330-338$. doi: 10.5539/ass.v11n10p330

[2] Atkinson, R.D., 2013. Competitiveness, Innovation and Productivity: Clearing up the Confusion. The Information Technology and Innovation Foundation.

[3] AWOKO, 2014. Sierra Leone news: Mineral Sector is Growing NMADG. Accessed (10.7.2016). http://awoko.org/2014/07/11/sierraleone-news-minerals-sector-is-growing-nmadg/

[4] Central Bank of Liberia, 2011. Annual Report, Monrovia, Liberia, p.38-40. Accessed (11.7.2016). http://www.cbl.org.lr/doc/annualreports/annualreport2011.pdf

[5] ECOWAS 2012 Annual Report. Integration and Political Stability in West Africa Extractive Industries Transparency Initiative, 2013. Report on Liberia. Accessed (11.7.2016).https://eiti.org/Liberia.

[6] Herath, J., Gebremedhin, T.G., and Maumbe, B.M .( 2011). A Dynamic Shift Share Analysis of Economic Growth in West Virginia. Journal of Rural and Community Development, Vol 6(2), 155-169.

[7] IBIS, 2014. Natural Resource Watch Report on Sierra Leone. Accessed (17.7.2016)

[8] International Monetary Fund, 2008. Guinea: Selected Issues and Statistical Appendix. IMF Country Report Number 08/20.

[9] Muhammad, N.M.N., Yaacob, H.C., 2008. Export Competitiveness of Malaysian Electrical and Electronic (E\&E) Product: Comparative Study of China, Indonesia and Thailand. International Journal of Business and Management Vol 3(7), 65-75.

[10] Mano River Union, 2015. Mano River Union Post-Ebola Socio-economic Recovery Soto-Viruet, Y., 2012. The Mineral Industries of Central African Republic, Cote D'Ivoire, and Togo. US Geological Survey Mineral yearbooks 2010.

[11] The Africa Competitiveness $\quad$ Report, $2013 . \quad$ Accessed http:/www.worldbank.org/content/dam/Worldbank/document/Africa/Report/africa competitiveness-report-2013-main-report-web.pdf

[12] The Africa Competitiveness Report, 2011. World Economic Forum, the World Bank and the African Development Bank. Accessed (11.7.2016). http://siteresources.worldbank.org/INTAFRICA/Resources/The_Africa_Competitiveness_Report_2011.pdf

[13] USAID, 2012. Artisanal Diamond Mining Sector Assessment in Cote D'Ivoire Consultancy Report. United States Geological Survey minerals yearbook- Sierra Leone, Guinea, and Liberia. 2005,2006, 2007, 2008, 2009, 2010, 2011, 2012, and 2013 reports

[14] Verma, S., 2002. Export Competitiveness of Indian Textile and Garment Industry. Indian Council for Research on International Economic Relations. Working Paper No.94. 
[15] Voon, J.P., 1998. Export Competitiveness of China and ASEAN in the US Market. Journal of ASEAN Economic Bulletin Vo1 4(3), 273291.

[16] Waters, J.J.( 2013). Achieving WTO Compliance for Export Processing Zones While Maintaining Economic Competitiveness for Developing Countries. Duke Law Journal Vol 63(481), 482-524.

[17] Wilson, P., Chern, T.S., Ping T.S., Robinson, E., 2005. A Dynamic Shift Share Analysis of the Electronics Export Market 1988-2001: Can the NIEs Compete with China? Singapore Centre for Applied and Policy Economics Working Paper Series, Paper No. 2005/07. Accessed (12.7.2016). http://nt2.fas.nus.edu.sg/ecs/pub/wp-scape/0507.pdf.

[18] Wilson, P., Chern, T.S., Ping, T.S., Robinson, E., Chuan, H.S., 2002. Assessing Singapore's Export Competitiveness through Dynamic Shift-Share Analysis. MAS Occasional Paper No 23.

[19] World Bank (2012). Increasing Local Procurement by the Mining Industry in West Africa.Report No 66585-AFR . Accessed (11.7.2015). http://siteresources.worldbank.org/INTENERGY2/Resources/8411-West_Africa.p 